\title{
Metastatic Renal Cell Carcinoma Management
}

\author{
Flavio L. Heldwein, Bernard Escudier, Gordon Smyth, Carlos A. V. Souto, Guy Vallancien \\ Department of Urology, Institut Mutualiste Montsouris (FLH, BE, GS, GV), Université Rene Descartes, Paris V, Paris, \\ France, Division of Urology, Santa Casa Hospital (CAVS), Porto Alegre, Brazil
}

\begin{abstract}
Purpose: To assess the current treatment of metastatic renal cell carcinoma, focusing on medical treatment options. Material and Methods: The most important recent publications have been selected after a literature search employing PubMed using the search terms: advanced and metastatic renal cell carcinoma, anti-angiogenesis drugs and systemic therapy; also significant meeting abstracts were consulted.

Results: Progress in understanding the molecular basis of renal cell carcinoma, especially related to genetics and angiogenesis, has been achieved mainly through of the study of von Hippel-Lindau disease. A great variety of active agents have been developed and tested in metastatic renal cell carcinoma (mRCC) patients. New specific molecular therapies in metastatic disease are discussed. Sunitinib, Sorafenib and Bevacizumab increase the progression-free survival when compared to therapy with cytokines. Temsirolimus increases overall survival in high-risk patients. Growth factors and regulatory enzymes, such as carbonic anhydrase IX may be targets for future therapies.

Conclusions: A broader knowledge of clear cell carcinoma molecular biology has permitted the beginning of a new era in mRCC therapy. Benefits of these novel agents in terms of progression-free and overall survival have been observed in patients with mRCC, and, in many cases, have become the standard of care. Sunitinib is now considered the new reference first-line treatment for mRCC. Despite all the progress in recent years, complete responses are still very rare. Currently, many important issues regarding the use of these agents in the management of metastatic renal cancer still need to be properly addressed.
\end{abstract}

Key words: renal cell carcinoma; neoplasm metastasis; anti angiogenetic agents; therapy

Int Braz J Urol. 2009; 35: 256-70

\section{INTRODUCTION}

Kidney cancer is responsible for more than 100,000 deaths per year (1). Renal cell carcinoma (RCC) remains one of the greatest challenges of urological oncology and is the third leading cause of death in genitourinary cancers. For unclear reasons, since the fifties, the annual incidence has risen by approximately $130 \%$. According to the U.S. Surveillance, Epidemiology and End-Results statistics, 45\% of these tumors have been diagnosed as locally advanced or metastatic disease and the two-year survival rates varies between 0 to $20 \%$ (2).
During the past decades, immunotherapies with cytokines based on interferon alpha (IFN-alpha) and interleukin-2 (IL2) have been the standard therapies for mRCC. Results with these standard therapies have been poor and with significant toxicities. Results with chemotherapy and hormonal agents have likewise been disappointing.

The usefulness of newer targeted therapies has been demonstrated in other malignancies such as gastro-intestinal stromal and colonic tumors, as well as leukemia. These therapies are directed at specific molecular targets implicated in angiogenesis and tumor proliferation. These encouraging results, coupled 
with a fuller understanding of molecular pathways in RCC have paved the way for new targets in the treatment of kidney cancer.

\section{TREATMENT OF METASTATIC DISEASE}

Conventionally, the following therapeutic modalities are available for patients with mRCC.

\section{Nephrectomy and/or Metastasectomy Alone}

Nephrectomy can improve quality of life and may, although rarely, induce spontaneous regression of metastases $(0.7 \%)$. If the metastases are resectable, nephrectomy with metastasectomy is the best treatment option for disseminated renal cell carcinoma. This, however, is applicable to less than $2-3 \%$ of patients and may be associated with significant perioperative morbidity and mortality (3).

Metastasectomy has provided a five-year survival rate of $25-60 \%$ for pulmonary metastases, $13-30 \%$ for a single osseous lesion, $50-75 \%$ for local recurrences. Regarding metastasectomies in cerebral lesions, if complete resection can be achieved, the 5year survival rate can be doubled when compared to observation, $13.8 \%$ vs. $7 \%$ respectively $(4,5)$. Advantages have been demonstrated when hepatectomy was performed in patients with single hepatic lesions (4).

\section{Neoadjuvant Cytoreductive Surgery and Immunotherapy}

Radical nephrectomy prolongs survival in metastatic patients when combined with cytokine therapy (6-8). This approach offers some theoretical advantages, such as prevention of complications during systemic treatment, reduction of tumor immunosuppressive potential, removal of the primary source of growth factors and providing tumor cells for analysis and experimental therapies. Non-randomized studies have demonstrated objective complete responses in $12.6 \%$ and partial responses of $39 \%(9)$.

The European Organization for Research and Treatment of Cancer has reported a trial (EORTC
30947) where patients with mRCC were randomized to IFN-alpha or INF-alpha plus radical nephrectomy. In the group submitted to radical nephrectomy, the overall survival increased from 7 to 17 months (6). Also, in the early 2000's, Flanigan et al. (Southwest Oncology Group Trial 8949) randomly investigated surgery followed by IFN-alpha vs. IFN-alpha alone, and also found a longer median survival in the combination arm (11.1 vs. 8.1 months; $p=0.05)$ (7).

Therefore, the standard of care in the immunotherapy era was cytoreductive nephrectomy prior to immunotherapy. Whether nephrectomy will be required in the new era of targeted therapy remains unclear and awaits clarification in future trials. Laparoscopic cytoreductive nephrectomy may serve to decrease the postoperative recovery time and therefore allow earlier initiation of systemic therapy.

\section{Initial Systemic Therapy Followed by Nephrectomy in Responders}

It seems logical to suppose that in patients who respond favorably to initial systemic therapy, cytoreductive nephrectomy would be beneficial. Benefits could include the possibility of down-staging the tumor and the sparing of the morbidity of surgery in the non-responders. However, there is a lack of evidence to support this approach, although survival results are promising $(10,11)$. There exist no reported data regarding the optimal timing of surgery or whether the morbidity of a later procedure is increased.

\section{Immunotherapy Alone}

Several controlled trials concerning immunotherapy in metastatic renal cell carcinoma (mRCC) have shown response rates of 2-39\% (12). However, in the majority of these trials, the patients had undergone nephrectomy before any evidence of clinical metastases, therefore the option of "immunotherapy alone" remains incompletely evaluated.

\section{Cytokines}

Treatments that combine chemotherapy and hormonal agents have had modest clinical benefits (5$10 \%$ ). However, immunotherapy produced objective 
response rates in the range of $10-20 \%$ with median stable disease (SD) of 3-16 months (13).

The clinical use of Interferon (IFN)-alpha and Interleukin(IL)-2 was extensively studied in the last decade and considered the first-line strategy in the treatment of mRCC. IL-2 was discovered in 1976 and described as a protein that promotes "in vitro" $\mathrm{T}$ cell growth.

A Cochrane review and a meta-analysis confirmed the value of IFN-alpha in mRCC. IFN-alpha provides response rates of $10-15 \%$ and complete responses in $1-2 \%$, however durable responders were rare $(14,15)$. Randomized trials comparing hormonal therapy and IFN resulted in a reduction of death risk of $28 \%$ in the IFN arm. The IFN group showed an improvement of 2.5 months in overall survival. Similar results were found when IFN was compared to chemotherapy (16).

Despite the low response rate to IFN, a significant improvement in survival was evident. Such benefit is now questionable, because it could be due to disease stabilization, which may occur in a great number of patients. Carbonic anhydrase IX (CA IX) expression may play a strategic role tumor progression or stabilization. Previous investigations have demonstrated that RCC without Von-Hipple Lindau (VHL) mutation showed lower CAIX expression and this is invariably associated with a highest malignant potential (17). Other biomarkers may also be of interest, such as levels of vascular endothelial growth factor (VEGF) and VEGFR subtypes and COX2 expression.

High dose intravenous IL2 can produce a complete response (CR) in selected patient cohorts. In a nonrandomized trial, approximately $9 \%$ of patients obtained a CR and 70-80\% maintained a prolonged response (17). IL2 and IFN have been shown to improve response rate and progression-free survival in a large randomized trial and may represent a good treatment option. Cytokine therapies have significant toxicity and IV regimens require intensive care but until recently they were the only treatment strategy available in mRCC.

\section{New Target-Therapies for Metastatic-RCC}

\section{Von-Hippel-Lindau Disease (VHL) and Molecular Targets}

In 1904, the German ophthalmologist Eugene Von Hippel reported a case of retinal angioma. Twenty years later, the Swedish pathologist Arvid Lindau described a central nervous system hemangioblastoma. However, it was only in 1928, that Cushing and Bailey described the syndrome. VHL affects approximately 1 in 35000 individuals. VHL is an autosomal dominant disease, whose genetic defect is located in chromosome 3p25-26 (18). The clinical manifestations are a variety of tumors in the retina, cerebellum, spinal cord, epididymis, pancreas, adrenals and kidneys. The VHL gene is highly preserved and present from insects to mammals, indicating biological importance in homeostasis.

Mutations of VHL gene are described in almost $100 \%$ of familial RCC. The incidence of RCC in VHL patients is $24-45 \%$ and they are all of the clear cell variety.

Also, VHL gene is often mutated in sporadic RCC and VHL disease molecular scheme serves as model for understanding the action mechanism of the new anti-angiogenic drugs. Inactivation of the VHL tumor suppressor gene induces a hyper-expression of genes regulated by hypoxia, including vascular endothelium grown factor (VEGF), platelet-derived growth factor (PDGF) among others (Table-1) (Figure-1).

Probably, the VHL mutation in RCC is an early event, because $80 \%$ of T1, low grade (G1-G2) and incidental tumors express such mutation. Therefore, other molecular routes are likely involved in RCC angiogenesis (19).

A better understanding of tumoral angiogenesis and the multiple signal routes implicated in renal cancer progression, have resulted in clinical use and in recent approval by European (EMEA) and US Agencies (FDA) of anti-angiogenic drugs for treat mRCC.

At least 5 emerging anti-angiogenic drugs are being intensively investigated. Initially, these drugs were investigated as second-line treatments in metastatic disease. Results have been promising and phase III trials were and are being conducted. A great number of trials are open, to study using them as first-line monotherapy or in horizontal and vertical combinations (Table-2).

However, there has been criticism of the current way to determine tumor response to these new agents. Critics argue that the traditional criteria based only in tumor size changes, the Response Evaluation 
Table 1 - Growth factors related to target therapies in renal cancer management.

\begin{tabular}{|c|c|c|c|}
\hline & Growth Factors & Receptor & Function \\
\hline HIF & $\begin{array}{l}\text { Hypoxia inducible factor } \\
\text { (subunits alpha and beta) }\end{array}$ & $\begin{array}{l}\text { Specific DNA } \\
\text { sequence }\end{array}$ & $\begin{array}{l}\text { Activates the transcription of target genes that codify } \\
\text { proteins as VEGF, PDGFR, TGF-alpha, EGF, erythro- } \\
\text { poietin. }\end{array}$ \\
\hline VEGF & $\begin{array}{l}\text { Vascular endothelial growth } \\
\text { factor }\end{array}$ & VEGFR & $\begin{array}{l}\text { Most potent pro-angiogenic. } \\
\text { Stimulates proliferation, metastases and inhibits apop- } \\
\text { tose. }\end{array}$ \\
\hline PDGF & $\begin{array}{l}\text { Platelet-derived growth } \\
\text { factor }\end{array}$ & PDGFR & $\begin{array}{l}\text { Tumoral proliferation through induction of DNA synthe- } \\
\text { sis, growth and apoptose inhibition. } \\
\text { Possibly a negative prognostic marker. }\end{array}$ \\
\hline EGF & Epidermal growth factor & $\begin{array}{c}\text { EGFR } \\
(\text { ErbB-1, } 2,3 \text { e } 4)\end{array}$ & $\begin{array}{l}\text { Stimulates VEGF production. } \\
\text { Negative prognostic marker. }\end{array}$ \\
\hline CAIX & Anhydrase carbonic IX & & $\begin{array}{l}\text { Regulates ions channels, } \mathrm{pH} \text {, hypoxia conditions. } \\
\text { Contributes to invasion and metastases. }\end{array}$ \\
\hline $\begin{array}{l}\text { TGF- } \\
\text { alpha }\end{array}$ & $\begin{array}{c}\text { Transforming growth factor } \\
\text { alpha }\end{array}$ & ErbB-1 & Induces angiogenesis and cell proliferation \\
\hline HGF & Hepatocyte grown factor & MET & Implicated in survival and dissemination \\
\hline
\end{tabular}

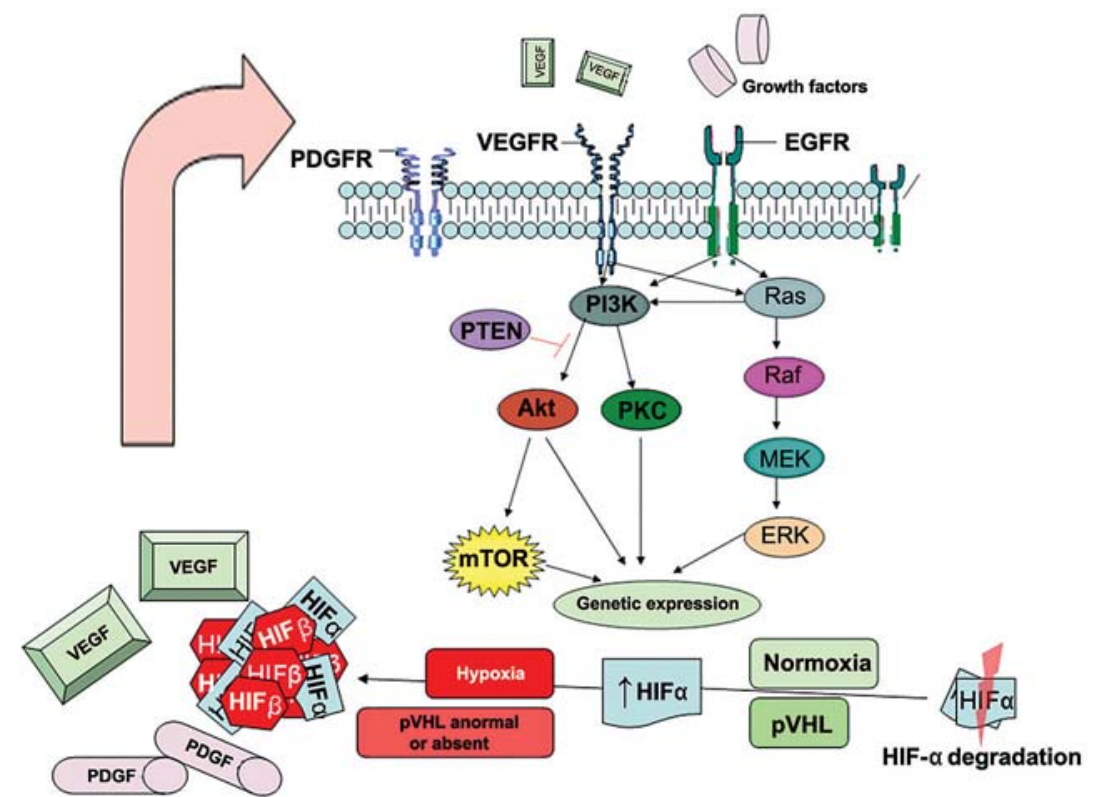

Figure 1 - Molecular scheme of mechanism of action of von Hippel-Lindau protein (VHL). In conditions of hypoxia or VHL gene inactivation and consequently, absence of codified protein ( $\mathrm{VVHL}$ ), there is no formation of complex formed by the binding of hypoxia inducible factor (HIF) and hydroxyproline residue. Therefore, there is no HIF degradation, resulting in accumulation of HIF in nucleus and promoting oncogenesis, through super-expression of encoding genes implicated in: tumoral angiogenesis (vascular endothelial growth factor [VEGF]), glucose transport (GLUT1, GLUT3), glycolisis (fosfofrutose-6 quinase-2), pH control (cabonic anhydrase family, CA IX), endothelial proliferation (platelet-derived growth factor [PDGF], transforming growth factor-alpha [TGF-alpha]), erythropoietin (EPO), cellular migration (CXCR4) and apoptosis (Bid, Bax, Bad) (15). 
Table 2 - Novel target agents in management of metastatic renal cell carcinoma.

\begin{tabular}{|c|c|c|c|}
\hline Agent & & Molecular Target & Action and Comments \\
\hline \multicolumn{4}{|l|}{ VEGF Inhibitors } \\
\hline Bevacizumab & Monoclonal antibody & VEGF & Inhibit angiogenesis \\
\hline VEGF Trap & & VEGF & Inhibit angiogenesis \\
\hline \multicolumn{4}{|l|}{ Tyrosine-kinases Inhibitors } \\
\hline $\begin{array}{l}\text { Sorafenib } \\
\text { (BAY 43-9006) }\end{array}$ & $\begin{array}{l}\text { Multi-tyrosine kinases } \\
\text { inhibitor }\end{array}$ & $\begin{array}{l}\text { C-RAF, B-RAF, * } \text { KIT }^{\dagger} \\
\text { VEGFR-2, VEGFR-3, } \\
\text { PDGFR-beta }\end{array}$ & $\begin{array}{l}\text { Inhibit tumoral growth } \\
\text { Inhibit angiogenesis }\end{array}$ \\
\hline $\begin{array}{l}\text { Sunitinib } \\
\text { (SU 11248) }\end{array}$ & $\begin{array}{l}\text { Multi-tyrosine kinases } \\
\text { receptors inhibitor }\end{array}$ & $\begin{array}{c}\text { KIT, FLT-3, }{ }^{\|} \text {RET } \\
\text { PDGFR, VEGFR } 1 \text {, } 2 \text { e } 3\end{array}$ & $\begin{array}{l}\text { Inhibit tumoral growth } \\
\text { Inhibit angiogenesis }\end{array}$ \\
\hline $\begin{array}{l}\text { Vatalanib } \\
\text { (PTK787/ZK222584) }\end{array}$ & TK receptors inhibitor & $\begin{array}{l}\text { VEGFR- } 1 \text { and } 2 \text {, } \\
\text { PDGFR }\end{array}$ & Inhibit angiogenesis \\
\hline $\begin{array}{l}\text { Axitinib } \\
\text { (AG-013736) }\end{array}$ & TK receptors inhibitor & $\begin{array}{l}\text { VEGFR-1, } 2 \text { and 3, } \\
\text { PDGFR-beta }\end{array}$ & Inhibit angiogenesis \\
\hline $\begin{array}{l}\text { Pazopanib } \\
\text { (GW786034) }\end{array}$ & $\begin{array}{l}\text { Multi-tyrosine kinases } \\
\text { inhibitor }\end{array}$ & $\begin{array}{c}\text { KIT } \\
\text { VEGFR-1, } 2 \text { and 3, } \\
\text { PDGFR-alpha and beta }\end{array}$ & $\begin{array}{l}\text { Inhibit cell proliferation } \\
\text { Inhibit angiogenesis }\end{array}$ \\
\hline Imatinib & TK inhibitor & PDGF & Inhibit angiogenesis \\
\hline (XL 880) & Dual TKI & MET, VEGFR2 & Inhibit grown, angiogenesis, dissemination \\
\hline \multicolumn{4}{|l|}{ EGF Inhibitors } \\
\hline $\begin{array}{l}\text { Lapatinib } \\
\text { (GW572016) }\end{array}$ & Selective inhibitor & EGFR (ErbB2) & Inhibit angiogenesis \\
\hline $\begin{array}{l}\text { Gefitinib } \\
\text { (ZD1839) }\end{array}$ & Selective inhibitor & EGFR (ErbB2) & $\begin{array}{l}\text { Inhibit angiogenesis } \\
\text { Inhibit cell proliferation }\end{array}$ \\
\hline $\begin{array}{l}\text { Erlotinib } \\
\text { (OSI-774) }\end{array}$ & Selective inhibitor & HER1/EGFR TK & Inhibit angiogenesis \\
\hline \multicolumn{4}{|l|}{ m-TOR Inhibitors } \\
\hline $\begin{array}{l}\text { Temsirolimus } \\
\text { (CCI-779) }\end{array}$ & Selective inhibitor & m-TOR** & $\begin{array}{l}\text { Inhibit tumoral growth, remaining in G1 } \\
\text { cell cycle. } \\
\text { Inhibit angiogenesis }\end{array}$ \\
\hline $\begin{array}{l}\text { Everolimus } \\
\text { (RAD-001) }\end{array}$ & Selective inhibitor & m-TOR & $\begin{array}{l}\text { Inhibit tumoral growth, remaining in G1 } \\
\text { cell cycle. } \\
\text { Inhibit angiogenesis }\end{array}$ \\
\hline \multicolumn{4}{|l|}{ Miscellaneous } \\
\hline Bortezomib (OS-341) & HIF inhibitor & Proteossoms & $\begin{array}{l}\text { Inhibit HIF degradation. } \\
\text { Great toxicity. }\end{array}$ \\
\hline Velociximab & Anti-integrin antibody & alpha5beta1 & \\
\hline G250 (WX-G250) & Selective inhibitor & CAIX $^{\dagger \dagger}$ & $\begin{array}{l}\text { Monoclonal antibody IgG1. } \\
\text { Not expressed in normal proximal tubular } \\
\text { epithelium. } \\
\text { Phase II trial in process. Less toxicity than } \\
\text { cytokines }\end{array}$ \\
\hline
\end{tabular}


Criteria in Solid Tumors (RECIST) probably is not the best way to determined if anti-angiogenic drugs works or not in clinical trials. Therefore, other endpoints, such as stable disease and progression-free survival should be considered to predict new agents' approval.

Based on pretreatment patient characteristics, independent prognostic indicators were identified in anti-angiogenic agents' trials and they are similar to those reported in cytokine era. Baseline risk factors that need to be considered in order to achieve the best possible outcome include time from diagnosis to treatment (if $<1 \mathrm{yr}$. vs. $\geq 1 \mathrm{yr}$.), age, performance status, RCC subtypes, site and size of metastases, symptoms, corrected calcium (20).

\section{Sunitinib Malate - SU11248 (Sutent ${ }^{\circledR}$ - Pfizer)}

Sunitinib is a small molecule, oral multitargeted tyrosine kinase inhibitor (TKI) whose target is several tyrosine-kinase receptors (TKR). Also, Sunitinib has an anti-tumoral action directly in some tumor cells and an anti-angiogenic action through selective inhibition of PDGFR-alpha and PDGFR-beta, VEGFR types 1 to 3, KIT and FLT3. Results of two phase II trials have been published, using Sunitinib as second-line therapy in $\mathrm{mRCC}$ refractory to cytokines $(19,21)$. These studies included 63 and 106 patients, respectively. The treatment was designed with Sunitinib $50 \mathrm{mg}$ /day for 4 weeks in repeated cycles to every 6 weeks. The principal adverse effects related were fatigue $(38 \%, 28 \%)$, diarrhea $(24 \%, 20 \%)$, nausea $(19 \%, 13 \%)$ and stomatitis $(19 \%, 14 \%)$. Laboratory abnormalities grade 3 and 4 (graduation in agreement with National Cancer Institute Common Terminology Criteria for Adverse Events - CTCAE, Version 3.0); such as neutropenia, anemia, thrombocytopenia and lipase increase were observed in 13\% and 16\%, 10\% and $6 \%, 0 \%$ and $6 \%$, and $21 \%$ and $17 \%$ in the two studies, respectively. The overall response rates were $40 \%$ and $44 \%$ and 3 -months SD was achieved in $28 \%$ and $23 \%$ of the cases, respectively. In general, $66 \%$ of the patients had some clinical benefit. The progression-free survival (PFS) was 8.7 and 8.3 months, respectively, the median survival was 16.4 months in the first study, and it was not reported in the second.

Such response rates, measured by RECIST criteria, had not been observed in second-line treat- ments in the conventional immunotherapy era. Figure2 shows an example of partial response with Sunitinib that is the new standard of care for mRRC.

A phase III trial comparing IFN-alpha and Sunitinib as first-line treatment for $\mathrm{mRCC}$ was recently completed. 750 patients were enrolled and randomized, $90 \%$ had undergone prior nephrectomy. The average PFS was longer in the Sunitinib group compared with the IFN group (11 vs. 5 months). Only one case of complete response was observed in Sunitinib group (22). Although not yet published, survival data analysis was orally presented in the 2008 American Society of Clinical Oncology (ASCO) Annual Meeting showing a survival benefit in favor of Sunitinib (23).

Currently, a great number of trials are open, combining Sunitinib with Gefitinib, Bevacizumab, Gemcitabine, Capecitabine or Interferon. Caution is recommended in associating Sunitinib and cytochrome P450, CYP3A4 inhibitors or inducers. Cardiovascular safety remains unknown.

\section{Sorafenib Tosilato - BAY 43-9006 (Nexavar ${ }^{\circledR}$ - Bayer)}

Sorafenib is an oral multi-kinase inhibitor and it has an antitumoral activity in xenograft models of human RCC. Initially, it was presumed that Sorafenib acted by inhibiting serine/treonine Raf-1 kinase. Inhibitor activity against B-Raf and other TK receptors as VEGFR-2, PDGF-R, FLT-3 and c-kit were proven.

Two phase II trials have been reported and have described significant clinical benefits in metastatic patients (recommended dose as $400 \mathrm{mg}$ orally twice daily). In one of these studies, 397 patients with several types of refractory solid tumors were included, of these, 89 patients had mRCC and SD was observed in $50 \%$ (24). In 2005, an interim analysis of a phase III trial were presented and final results published in 2007 (TARGET - Treatment Approaches in Renal Global Cancer Evaluation Trial), that compared Sorafenib and placebo in refractory metastatic patients (25). A dose modification was necessary in $25 \%$ of the patients who presented with adverse events. Treatment was discontinued in $38 \%$, however, only $9 \%$ discontinued the treatment because of adverse effects. The more common side effects were skin rash 

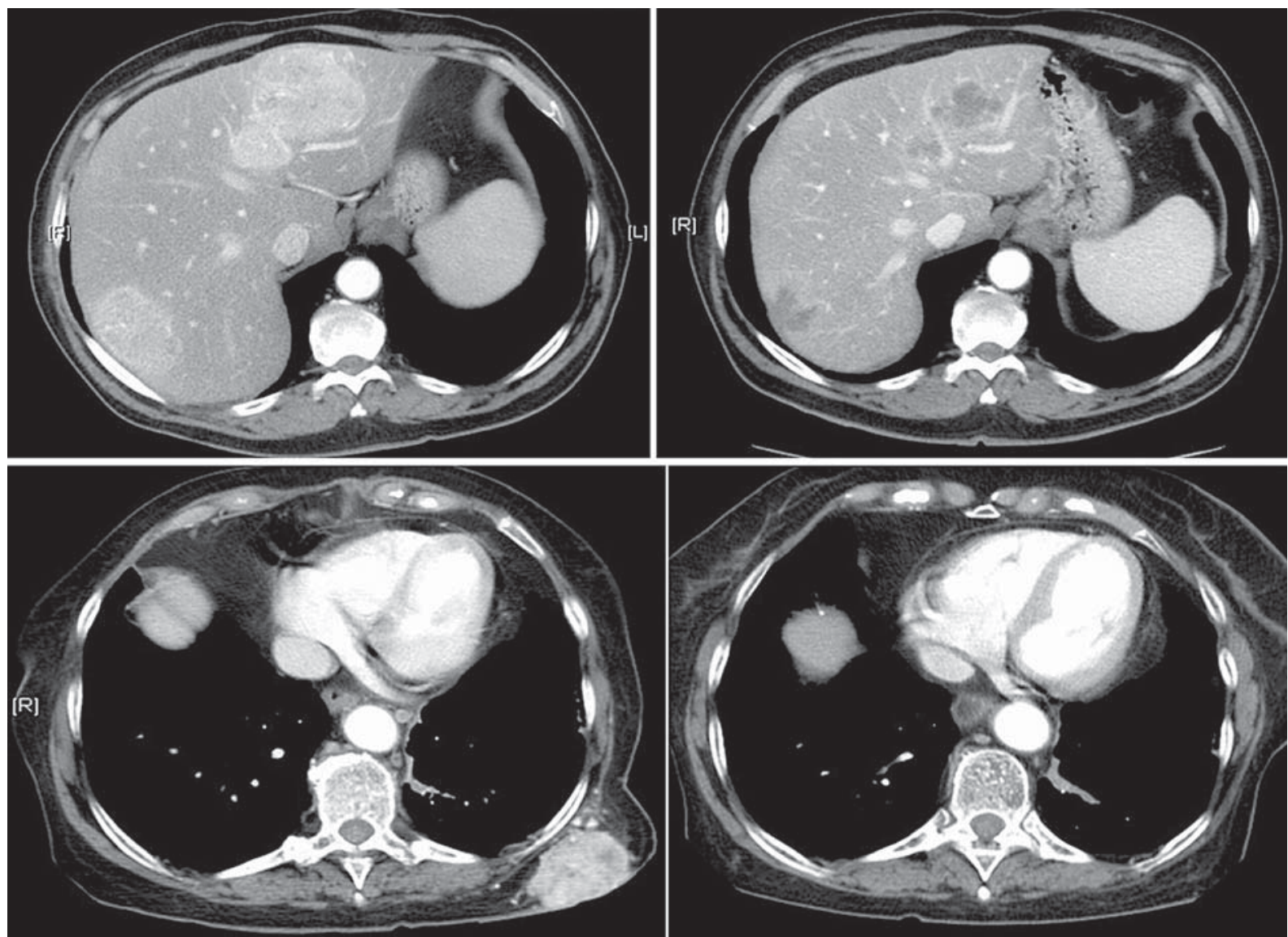

Figure 2 - Axial CT image showing examples of partial response of a renal cell carcinoma metastases in liver and lung.

or desquamation $(31 \%)$, diarrhea $(30 \%)$, hand-foot skin syndrome (26\%) and fatigue (18\%). Hypertension $(8 \%)$ and neuropathy $(9 \%)$ were rarely observed. No significant hematological or biochemical toxicity was observed. Eighty percent of the patients showed a clinical benefit. In the Sorafenib group, a PR was achieved in just $2 \%$, but SD was observed in $78 \%$, while in the placebo arm there were no PR and SD was seen in $55 \%$. The PFS was 24 weeks in the Sorafenib arm, against 12 weeks in the placebo arm $(p<0.000001)$. Because of this prolongation of the PFS, the protocol TARGET was modified, allowing patients in the placebo arm to be crossed-over for treatment with Sorafenib (Figure-3).

A phase II trial comparing first-line Sorafenib vs. IFN was presented at ASCO 2007 and there was no difference in PFS between both arms (26). Ryan et al. and SWOG presented a phase II trial, where
Sorafenib was combined with IFN as first-line therapy. In 62 patients, PR was achieved in 19\% and a PFS in $50 \%(27)$.

Bevacizumab (Avastin ${ }^{\circledR}$ - Genentech - Roche)

Bevacizumab is an anti-VEGF monoclonal humanized recombinant antibody (anti-VEGF MoAb) that recognizes all VEGF isoforms and has a prolonged half-life (17-21 days). Yang et al. first reported results of a randomized phase II study that compared patients with $\mathrm{mRCC}$ refractory to cytokine therapy. One hundred and sixteen patients were randomized into 3 groups: 40 patients to placebo, 37 to the Bevacizumab group at a dose of $3 \mathrm{mg} / \mathrm{kg}$ and 39 patients $10 \mathrm{mg} / \mathrm{kg} \mathrm{q} 2 \mathrm{w}$. PFS (4.8 months) was increased significantly in high-dose Bevacizumab, compared with placebo (2.5 months) $(\mathrm{p}=0.001)(28)$. The high-dose Bevacizumab group reached PR of $10 \%$. The prob- 

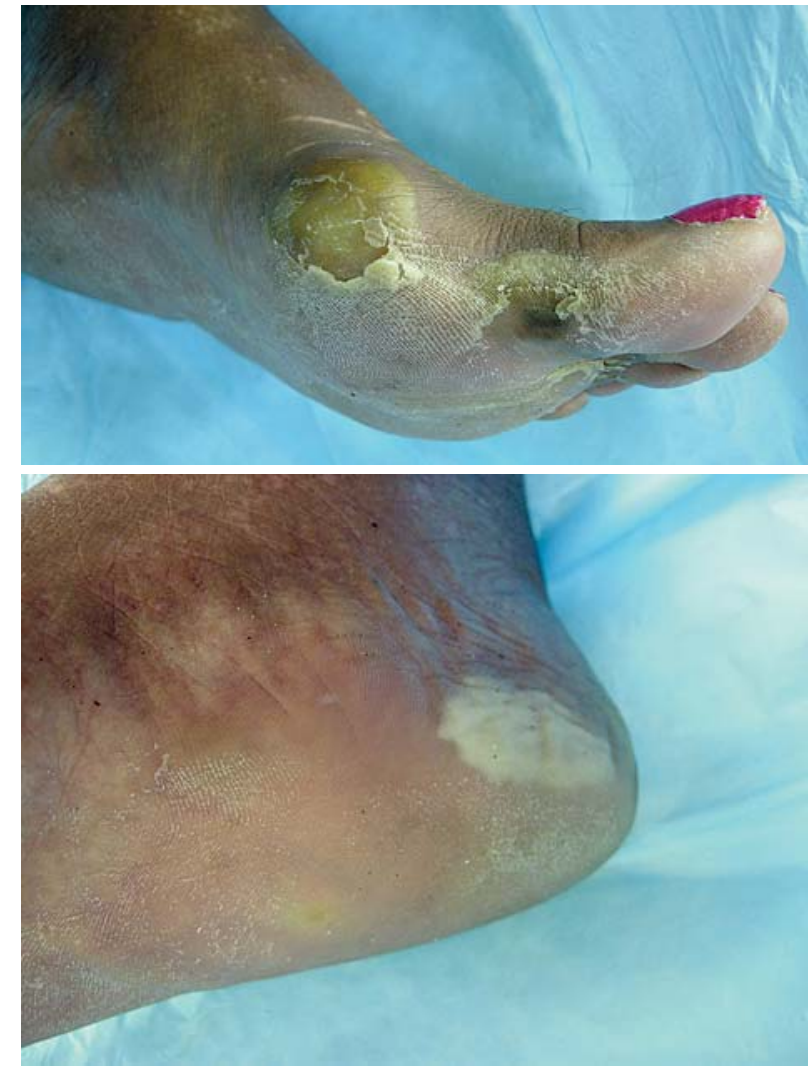

Figure 3 - Hand-foot skin syndrome (courtesy of: Dr. Lacouture).

ability of PFS for patients that received this antibody in high-dose, low-dose and placebo were $64 \%, 39 \%$ and $20 \%$ in 4 months, and $30 \%, 14 \%$ and $5 \%$ to the 8 months, respectively. The study was interrupted after interim analysis because of the differences observed in PFS. Usually, the treatment was well tolerated: hypertension, malaise and proteinuria were the most common side effects.

Combinations between Bevacizumab and other drugs are currently under investigation. Although monotherapies targeted against epidermal grown factor receptor (EGFR) have yielded disappointing results, Hainsworth et al. published their results in 63 patients with metastatic RCC associating Bevacizumab $10 \mathrm{mg} / \mathrm{kg} 2 / 2$ weeks and Erlotinib 150 mg oral daily (29). The treatment was usually well tolerated. At 8 weeks, $25 \%$ of patients had an objective response with SD in $61 \%$. Another study, comparing Bevacizumab with thalidomide versus Bevacizumab alone, demonstrated similar toxicity and PFS (30).
However, the combination therapy with Bevacizumab, Erlotinib and Imatinib, did not provide additional clinical benefit and the toxicity was higher (29).

Results of two phase III trials have been published. Patients were randomized to IFN-alpha alone, IFN-alpha plus placebo or IFN-alpha with Bevacizumab (randomized open label design CALGB 90206; $\mathrm{n}=732$, and BO17705/Avoren; $\mathrm{n}=649$ ) $(31,32)$. Escudier et al. recently published the results of a phase III trial. The Avoren study enrolled 649 untreated $\mathrm{mRCC}$ patients, to receive IFN-alpha (9 MIU subcutaneously 3x/week) and Bevacizumab $(10 \mathrm{mg} / \mathrm{kg} \mathrm{q} 2 \mathrm{w} ; \mathrm{n}=327)$ or placebo and IFN-alpha $(\mathrm{n}=322)$. The study was not blinded after an interim analysis, because PFS was significantly improved in the combined group compared to IFN (10.2 months vs. 5.4 months, $p=0.0001$ ) irrespective of risk group (32). Results of CALGB 90206 are available in abstract form. In this trial, the PFS was significantly increased in the Bevacizumab plus IFN arm compared to IFN alone ( 8.5 to 5.2 months; $p=0.0001$ ). Also the combination produces more objective responses ( $25 \%$ vs. $13 \% ; p=0.0001)$. Data concerning overall survival are not available (31).

Finally, many other combinations are being studied with Bevacizumab and other drugs, such as high-dose IL-2 and IL-2 subcutaneous. Further combination studies are ongoing with Sorafenib, Sunitinib and temsirolimus, such as the phase II BeST trial.

\section{Temsirolimus - CCI-779 (Torisel ${ }^{\circledR}$ - Wyeth Phar- maceuticals) \\ CCI-779 (rapamycin-42-[2,2-bis-(hydroxy-} methyl)]-propionate) is a specific inhibitor of mTOR kinase, a serine/treonine kinase that plays a fundamental part in cell cycle regulation. The mTOR has an effector role in phosphadityl-inositol-3-kinase and Akt signaling pathways. The suppressor gene called PTEN regulates Akt and mTOR activity, whose activation, increases hypoxia inductive factor (HIF). This gene is frequently methylated in RCC (33).

In 2004, Atkins et al., reported a phase II study including 111 patients with refractory $\mathrm{mRCC}$, with PR in $7 \%$. The global clinical benefit was $51 \%$, median PFS was 5.8 months and overall survival was 15 months with $26 \%$ of patients alive after 2 years (34). In the same year, a phase I study evaluated Temsiro- 
limus in combination with IFN. The maximum dose of Temsirolimus was $15 \mathrm{mg} /$ week with IFN-alpha 6 MU 3x/week. Seventy-one patients with mRCC were included and the objective response rate was $11 \%$, while the global clinical benefit was $41 \%$ and PFS was 9.1 months (35).

In 2007, Hudes et al. published the results of the Global ARCC trial, a randomized phase III trial with 3 arms: IFN alone, IFN with Temsirolimus and Temsirolimus alone. A total of 626 patients were randomized. $67 \%$ had had a prior nephrectomy and $80 \%$ had clear cell histology. The overall survival was increased in the temsirolimus group when compared to IFN (10.9 vs. 7.4 months; $p=0.001)$. This study concluded that monotherapy with Temsirolimus increases overall survival in high risk patients (33). In May 2007, Temsirolimus was approved by the FDA for the treatment of mRCC. Temsirolimus is also being studied versus Sorafenib in patients who have failed first-line Sunitinib.

\section{Everolimus - RAD-001 (Certican ${ }^{\circledR}$ - Novartis)}

Everolimus is a rapamycin analogue and an oral mTOR inhibitor. It was studied as second-line therapy in 25 patients, with a dose of $10 \mathrm{mg} /$ day in a 28 day cycle. Objective responses of $33 \%$ were obtained and side effects were mucositis, rash, hyperglycemia (36).

A placebo-controlled phase III trial investigated second-line RAD001 after failure of TKIs (RECORD-1 trial). After documented progression, patients placed initially in placebo group were able to crossover to receive everolimus. Preliminary results demonstrated that RAD-001 improved PFS over placebo in patients who previously failed TKI therapy (4.6 months vs. 1.8 months, respectively). There was no difference in terms of overall survival, perhaps due to crossover (37).

\section{Vatalanib - PTK787/ZK222584 (Novartis Pharmaceuticals)}

PTK787/ZK222584 is an oral inhibitor of tyrosine-kinase receptors VEGFR-1, VEGF-R-2 and PDGF-R. In phase I/II studies measurable responses in 7 of 37 patients $(19 \%)$ were observed and SD was achieved in $46 \%$, while PFS was of 5.5 months (38).
Axitinib - AG-013736 (Pfizer)

AG-013736 is a TK receptors inhibitor through a proven role on VEGFR-1, 2 and 3, PDGFR-beta and c-kit by image perfusion and capillary permeability studies.

Rini et al. demonstrated anti tumoral effects of AG013746 in a phase II study that include 52 patient $\mathrm{mRCC}$ refractory to systemic treatment with cytokines (IL-2). The oral dose of $5 \mathrm{mg} \mathrm{2x}$ /day was instituted until disease progression or unacceptable toxicity. No patient obtained complete response, $40 \%$ had PR and $28 \%$ SD, with a clinical benefit of $69 \%$. The treatment was discontinued in $54 \%$ of patients however only $12 \%$ of suspension were due to side effects (39). A Phase 3 study comparing Axitinib to Sorafenib in patients who fail Sunitinib was due to commence in 2008.

\section{Pazopanib - GW786034 (Glaxo Smith Kline)}

Pazopanib is another oral TKI and inhibitor of VEGFR, PDGFR and c-kit. Initial studies demonstrate antitumoral activity in several tumors. In one study 3 of 3 mRCC patients showed some clinical benefit. Interim analysis of a phase II trial, analyzed the role of Pazopanib as cytokine naïve and refractory patients. Based on a consistent response rate of $27 \%$ observed after 60 treated patients, the randomization was discontinued and the study continued as a single-label, single-arm study. Drug related grade 3 or 4 adverse events were observed in $37 \%$ of the patients and $11 \%$ of the patients discontinued the treatment (40). A phase III trial is ongoing.

\section{Lapatinib (GSK)}

Lapatinib is an oral selective and reversible inhibitor of EGFR and ErbB2. EGFR is expressed in the majority of mRCC patients. In a phase III trial, used as second-line versus hormones the PFS was not significantly different, however, retrospectively, in selected patients, who demonstrated EGFR superexpression, the PFS was longer. The principal side effects were rash and diarrhea (41).

\section{Volociximab - M200 (PDL BioPharm and Biogen Idec)}

This is an immunoglobulin chimerical G4 $\mathrm{MoAb}$ that binds a5beta1, an integrin with a critical 
role in the final pathway of tumoral proliferation and angiogenesis. In a phase II study, patients received volociximab $10 \mathrm{mg} / \mathrm{Kg}$ IV q2 weeks as a second-line therapy until progression. SD was obtained in $80 \%$ of the patients and PFS was greater than 113 days (42). It is a new promising drug and a higher dose is now being evaluated.

Other agents that play a role in the molecular regulation routes of RCC are under evaluation, some with promising pre clinical results (Figure-4).

\section{Bortezomib - PS-341 (Velcade ${ }^{\circledR}$, Millennium Pharmaceuticals)}

This is derived from boronic acid that inhibits the proteosome, stabilizing its active site by a reversible inhibition of the activity of chymotripsin-like, essential for the degradation of many intracellular proteins, such as HIF. Phase II studies investigated the use of PS-341 in mRCC. Minor clinical activity with significant toxicity, make the use of Bortezomib unlikely in the clinical setting. Other HIF inhibitors are in development (43).

\section{VEGF-Trap (Regeneron Pharmaceuticals)}

VEGF Trap is an inhibitor composed of VEGFR 1 and 2 parts that bind and neutralize all the VEGF-A isoforms. Six-months SD was obtained in a patient with $\mathrm{mRCC}(44)$.

\section{WX-G250 (Rencarex ${ }^{2}$, Wilex, Germany)}

cG250 is an immunoglobulin IgG1 that links to the $\mathrm{MN}$ antigen of the carbonic anhydrase IX found in almost $95 \%$ of RCC. Results of phase II studies, where G250 was combined with IFN-alpha and IL-2, did not show increase in toxicity, and a promising rate of SD and PR (45). A large randomized phase 3 trial of G250 in the adjuvant setting has just completed enrollment.

The great majority of anti-angiogenic trials have been designed for investigation of the clear cell subtype (Table-3). However, about $20 \%$ of RCC had a different histology and the real role of target therapies in these tumors is unclear. Specific studies for those subtypes are undergoing. A phase II trial, is investigating XL 880 (XL880® - Exelixis)

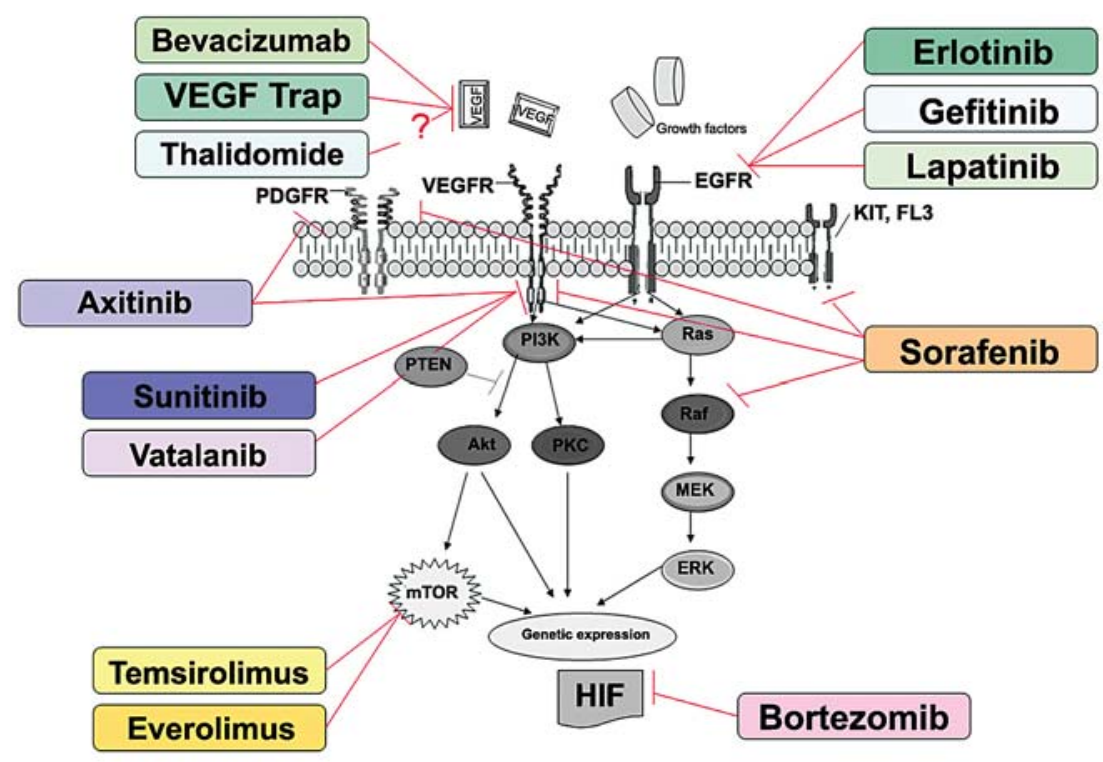

Figure 4 - Therapeutic targets of some anti-angiogenesis therapies for metastatic RCC. 
Table 3 - Systemic therapies for metastatic renal cell carcinoma.

\begin{tabular}{|c|c|c|c|c|}
\hline & $\begin{array}{c}\text { N. of } \\
\text { Patients }\end{array}$ & Phase Trial & $\begin{array}{c}\text { Objective } \\
\text { Response Rate, } \\
(\mathbf{C R}+\mathbf{P R}) \%\end{array}$ & Reference \\
\hline Chemotherapy & 1347 & $\begin{array}{l}\text { II } \\
51 \text { trials }\end{array}$ & 5 & Motzer et al., 2000. (14) \\
\hline IFN-alpha* & 963 & 6 trials & 12 & Coppin et al., 2005. (15) \\
\hline High-dose IL- $2^{*} \star$ & 255 & II & 14 & Fyfe et al., 1995. (47) \\
\hline IFN-alpha plus IL-2 & 607 & $\begin{array}{c}\text { II } \\
23 \text { trials }\end{array}$ & 19 & $\begin{array}{c}\text { Vogelzang et al., } 1993 . \\
\text { (48) }\end{array}$ \\
\hline $\begin{array}{l}\text { IFN-alpha }+ \text { cytoreduction } \\
\text { EORTC } 30947\end{array}$ & 42 & $\begin{array}{c}\text { III } \\
1^{\text {st }} \text { vs. IFN alone }\end{array}$ & 19 vs. 12 & Mickisch et al., 2001. (6) \\
\hline Sorafenib ${ }^{*}+$ & 903 & $\begin{array}{c}\text { III } \\
2^{\text {nd }} \text { line vs. placebo }\end{array}$ & $\begin{array}{c}10 \text { vs. } 2 \\
(\mathrm{SD} 74 \%)\end{array}$ & Escudier et al., 2007. (25) \\
\hline Sorafenib plus IFN-alpha & 62 & $\begin{array}{c}\text { II } \\
1^{\text {st }} \text { line }\end{array}$ & $\begin{array}{c}19 \\
(\mathrm{SD} 50 \%)\end{array}$ & Ryan et al., 2007. (27) \\
\hline Sunitinib* & 750 & $\begin{array}{c}\text { III } \\
1^{\text {st }} \text { line vs. IFN- } \\
\text { alpha }\end{array}$ & 31 vs. 6 & Motzer et al., 2007. (22) \\
\hline Temsirolimus** & 626 & $\begin{array}{c}\text { III } \\
1^{\text {st }} \text { line vs. IFN- } \\
\text { alpha }\end{array}$ & 9 vs. 7 & Hudes et al., 2007. (33) \\
\hline Everolimus & 25 & $\begin{array}{c}\text { II } \\
2^{\text {nd }} \text { line }\end{array}$ & 33 & Amato et al., 2006. (36) \\
\hline Everolimus & 410 & $\begin{array}{c}\text { III } \\
2^{\text {nd }} \text { line vs. placebo }\end{array}$ & $\begin{array}{c}1 \\
(\mathrm{SD} 63 \text { vs. 32\% })^{\dagger}\end{array}$ & Motzer et al., 2008. (37) \\
\hline Bevacizumab & 116 & $\begin{array}{c}\text { II } \\
2^{\text {nd }} \text { line }\end{array}$ & 10 & Yang et al., 2003. (28) \\
\hline Bevacizumab + IFN-alpha & 649 & $\begin{array}{c}\text { III } \\
1^{\text {st }} \text { line vs. IFN- } \\
\text { alpha }\end{array}$ & 31 vs. 13 & Escudier et al., 2007. (32) \\
\hline Pazopanib & 225 & $\begin{array}{c}\text { II } \\
1^{\text {st }} \text { and } 2^{\text {nd }} \text { line }\end{array}$ & $\begin{array}{c}30 \\
(\mathrm{SD} 73 \%)^{\dagger}\end{array}$ & Hutson et al., 2007. (40) \\
\hline Axitinib & 52 & $\begin{array}{c}\text { II } \\
2^{\text {nd }} \text { line }\end{array}$ & 40 & Rini et al., 2005. (39) \\
\hline Volociximab & 40 & $\begin{array}{c}\text { II } \\
2^{\text {nd }} \text { line }\end{array}$ & $\left(\begin{array}{c}- \\
\text { SD } 87 \%)\end{array}\right.$ & Figlin et al., 2006. (42) \\
\hline Bortezomib & 37 & $\begin{array}{c}\text { II } \\
2^{\text {nd }} \text { line }\end{array}$ & 11 & $\begin{array}{c}\text { Kondagunta et al., } 2004 . \\
\text { (43) }\end{array}$ \\
\hline Gefitinib & 21 & $\begin{array}{c}\text { II } \\
2^{\text {nd }} \text { line }\end{array}$ & No & Dawson et al., 2004. (49) \\
\hline
\end{tabular}

$*$ = drugs approved by FDA (USA Food and Drugs Administration); + = drugs approved by EMEA (European Medicines Agency); $+=$ interim analysis; $C R=$ complete response; $P R=$ partial response; $S D=$ stable disease 
in papillary renal cell carcinoma. XL 880 is a potent dual TK receptor inhibitor, the primary targets of which are VEGFR2 and MET receptors. Hereditary and sporadic papillary RCC have in common MET over-expression or mutation. Interim data have been reported and 6-months SD was achieved in 12/16 patients (46).

Concerning sequential and combination therapy, efforts should be made to clarify several clinical issues regarding the optimal use of these drugs, specially the possibility of cross-resistance to agents acting against the same targets. Clinically, resistance to anti-angiogenic agents has been described. To date, mechanisms of resistance and other issues of chronic anti-angiogenic use remains largely unclear. In vitro studies have suggested that mutations of TK receptors could be responsible for molecular resistance.

\section{CONCLUSIONS}

For years, the major progress in the management of renal cell carcinoma has been achieved in localized disease. Relevant advances in molecular biology permit the development of new drugs to treat metastatic patients. The usefulness of nephrectomy as neoadjuvant therapy in $\mathrm{mRCC}$ was confirmed in the cytokine era and surgical resection of metastases had a positive impact on prognosis, however if nephrectomy remains an integral part of $\mathrm{mRCC}$ management in this new era is unknown.

Analysis of the most recent clinical data recommended Sunitinib as first-line treatment for favorable and intermediate risk profile. Similarly, Bevacizumab given in combination with IFN-alpha demonstrated benefit and is an alternative option. Temsirolimus showed efficacy in patients stratified into poor risk group ( $\geq 3$ risk factors) and should be considered an option for first-line use in this group. To date, IL-2 might be an alternative treatment for a select good risk group with clear-cell histology. Sorafenib is recommended for $\mathrm{mRCC}$ after failure of prior systemic first-line strategies.

The results from new targeted therapy trials give much cause for encouragement in the treatment of $\mathrm{mRCC}$, and are fast becoming the new standard of care.
It is imperative that urologists and clinical oncologists work together, participating in trials to answer further pressing questions. What is the standard regime? Should monotherapy or combinations be used? What is the optimal dose and schedule? What are the treatment options for non-clear cell subtypes? What is the role of neoadjuvant therapy, by cytoreductive surgery or systemic therapies? In the area of adjuvant therapy, drugs that act on pathways of cellular proliferation may have a role. New drugs are being developed and used in clinical trials, in combination or as single agents, and show promising preliminary results. Future analysis of biomarkers may well provide data to aid in the selection of subgroups and define follow-up strategies in mRCC.

\section{ACKNOWLEDGEMENTS}

Dr. Ernani Rhoden, Department of Urology, Federal Faculty of Medical Sciences, critical review this manuscript.

\section{CONFLICT OF INTEREST}

Dr. Escudier receives consulting fees and lecture fees from Roche, Bayer, Wyeth, Pfizer, Inate, and Antigenics. Dr. Guy Vallancien is a study investigator of Sanofi-Aventis.

\section{REFERENCES}

1. Parkin DM, Bray F, Ferlay J, Pisani P: Global cancer statistics, 2002. CA Cancer J Clin. 2005; 55: 74-108.

2. Jemal A, Siegel R, Ward E, Hao Y, Xu J, Murray T, et al.: Cancer statistics, 2008. CA Cancer J Clin. 2008; 58: 71-96.

3. Jacqmin D, van Poppel H, Kirkali Z, Mickisch G: Renal cancer. Eur Urol. 2001; 39: 361-9.

4. van der Poel HG, Roukema JA, Horenblas S, van Geel AN, Debruyne FM: Metastasectomy in renal cell carcinoma: A multicenter retrospective analysis. Eur Urol. 1999; 35: 197-203.

5. Ljungberg B, Landberg G, Alamdari FI: Factors of importance for prediction of survival in patients with metastatic renal cell carcinoma, treated with or without 
nephrectomy. Scand J Urol Nephrol. 2000; 34: 24651 .

6. Mickisch GH, Garin A, van Poppel H, de Prijck L, Sylvester R; European Organisation for Research and Treatment of Cancer (EORTC) Genitourinary Group: Radical nephrectomy plus interferon-alfa-based immunotherapy compared with interferon alfa alone in metastatic renal-cell carcinoma: a randomised trial. Lancet. 2001; 358: 966-70.

7. Flanigan RC, Salmon SE, Blumenstein BA, Bearman SI, Roy V, McGrath PC, et al.: Nephrectomy followed by interferon alfa- $2 b$ compared with interferon alfa- $2 b$ alone for metastatic renal-cell cancer. N Engl J Med. 2001; 345: 1655-9.

8. Flanigan RC, Mickisch G, Sylvester R, Tangen C, Van Poppel H, Crawford ED: Cytoreductive nephrectomy in patients with metastatic renal cancer: a combined analysis. J Urol. 2004; 171: 1071-6.

9. Rackley R, Novick A, Klein E, Bukowski R, McLain D, Goldfarb D: The impact of adjuvant nephrectomy on multimodality treatment of metastatic renal cell carcinoma. J Urol. 1994; 152: 1399-403.

10. Harshman LC, Srinivas S: Current status of cytoreductive nephrectomy in metastatic renal cell carcinoma. Expert Rev Anticancer Ther. 2007; 7: 1749-61.

11. Bex A, Kerst M, Mallo H, Meinhardt W, Horenblas $\mathrm{S}$, de Gast GC: Interferon alpha $2 \mathrm{~b}$ as medical selection for nephrectomy in patients with synchronous metastatic renal cell carcinoma: a consecutive study. Eur Urol. 2006; 49: 76-81.

12. Duensing S, van den Berg-de Ruiter E, Störkel S, Kirchner H, Hänninen EL, Buer J, et al.: Cytogenetic studies in renal cell carcinoma patients receiving lowdose recombinant interleukin-2-based immunotherapy. Tumour Biol. 1996; 17: 27-33.

13. Horoszewicz JS, Murphy GP: An assessment of the current use of human interferons in therapy of urological cancers. J Urol. 1989; 142: 1173-80.

14. Motzer RJ, Russo P: Systemic therapy for renal cell carcinoma. J Urol. 2000; 163: 408-17.

15. Coppin C, Porzsolt F, Kumpf J, Coldman A, Wilt T: Immunotherapy for advanced renal cell cancer. Cochrane Database Syst Rev. 2000; 3: CD001425. Update in: Cochrane Database Syst Rev. 2005; 1: CD001425.

16. No authors listed: Interferon-alpha and survival in metastatic renal carcinoma: early results of a randomised controlled trial. Medical Research Council Renal Cancer Collaborators. Lancet. 1999; 353: 14-7.

17. Larkin JM, Eisen T: Kinase inhibitors in the treatment of renal cell carcinoma. Crit Rev Oncol Hematol. 2006; 60: 216-26.
18. Latif F, Tory K, Gnarra J, Yao M, Duh FM, Orcutt ML, et al.: Identification of the von Hippel-Lindau disease tumor suppressor gene. Science. 1993; 260: 1317-20.

19. Motzer RJ, Michaelson MD, Redman BG, Hudes GR, Wilding G, Figlin RA, et al.: Activity of SU11248, a multitargeted inhibitor of vascular endothelial growth factor receptor and platelet-derived growth factor receptor, in patients with metastatic renal cell carcinoma. J Clin Oncol. 2006; 24: 16-24.

20. Choueiri TK, Garcia JA, Elson P, Khasawneh M, Usman S, Golshayan AR, et al.: Clinical factors associated with outcome in patients with metastatic clear-cell renal cell carcinoma treated with vascular endothelial growth factor-targeted therapy. Cancer. 2007; 110: 543-50.

21. Motzer RJ, Rini BI, Bukowski RM, Curti BD, George DJ, Hudes GR, et al.: Sunitinib in patients with metastatic renal cell carcinoma. JAMA. 2006; 295: 251624.

22. Motzer RJ, Hutson TE, Tomczak P, Michaelson MD, Bukowski RM, Rixe O, et al.: Sunitinib versus interferon alfa in metastatic renal-cell carcinoma. N Engl J Med. 2007; 356: 115-24.

23. Figlin RA, Hutson TE, Tomczak P, Michaelson MD, Bukowski RM, Négrier S, et al.: Overall survival with sunitinib versus interferon (IFN)-alfa as first-line treatment of metastatic renal cell carcinoma (mRCC). J Clin Oncol. 2008; 26: (suppl. 20) Abstract 5024.

24. Ratain MJ, Eisen T, Stadler WM, Flaherty KT, Kaye SB, Rosner GL, et al.: Phase II placebo-controlled randomized discontinuation trial of sorafenib in patients with metastatic renal cell carcinoma. J Clin Oncol. 2006; 24: 2505-12.

25. Escudier B, Eisen T, Stadler WM, Szczylik C, Oudard $\mathrm{S}$, Siebels M, et al.: Sorafenib in advanced clear-cell renal-cell carcinoma. N Engl J Med. 2007; 356: 125 34. Erratum in: N Engl J Med. 2007; 357: 203.

26. Szczylik C, Demkow T, Staehler M, Rolland F, Negrier S, Hutson TE, et al.: Randomized phase II trial of first-line treatment with sorafenib versus interferon in patients with advanced renal cell carcinoma: Final results. J Clin Oncol. 2007; 25: (Suppl. Part I. 18S) Abstact 5025.

27. Ryan CW, Goldman BH, Lara PN Jr, Mack PC, Beer TM, Tangen CM, et al.: Sorafenib with interferon alfa$2 \mathrm{~b}$ as first-line treatment of advanced renal carcinoma: a phase II study of the Southwest Oncology Group. J Clin Oncol. 2007; 25: 3296-301.

28. Yang JC, Haworth L, Sherry RM, Hwu P, Schwartzentruber DJ, Topalian SL, et al.: A randomized trial 
of bevacizumab, an anti-vascular endothelial growth factor antibody, for metastatic renal cancer. N Engl J Med. 2003; 349: 427-34.

29. Hainsworth JD, Spigel DR, Sosman JA, Burris HA 3rd, Farley C, Cucullu H, et al.: Treatment of advanced renal cell carcinoma with the combination bevacizumab/erlotinib/imatinib: a phase I/II trial. Clin Genitourin Cancer. 2007; 5: 427-32.

30. Elaraj DM, White DE, Steinberg SM, Haworth L, Rosenberg SA, Yang JC: A pilot study of antiangiogenic therapy with bevacizumab and thalidomide in patients with metastatic renal cell carcinoma. J Immunother. 2004; 27: 259-64.

31. Rini BI, Halabi S, Rosenberg JE, Stadler WM, Vaena D, Ou S, et al.: CALGB 90206: A phase III trial of bevacizumab plus interferon-alpha versus interferon-alpha monotherapy in metastatic renal cell carcinoma. 2008; 2008 Genitourinary Cancers Symposium (abstract\# 350). Available at: http://www. asco.org/ASCO/Abstracts+\%26+Virtual+Meeting/ Abstracts? \&vmview $=$ abst_detail_view\&confID $=54$ \&abstractID $=20357$

32. Escudier B, Pluzanska A, Koralewski P, Ravaud A, Bracarda S, Szczylik C, et al.: Bevacizumab plus interferon alfa-2a for treatment of metastatic renal cell carcinoma: a randomised, double-blind phase III trial. Lancet. 2007; 370: 2103-11.

33. Hudes G, Carducci M, Tomczak P, Dutcher J, Figlin $\mathrm{R}$, Kapoor A, et al.: Temsirolimus, interferon alfa, or both for advanced renal-cell carcinoma. N Engl J Med. 2007; 356: 2271-81.

34. Atkins MB, Hidalgo M, Stadler WM, Logan TF, Dutcher JP, Hudes GR, et al.: Randomized phase II study of multiple dose levels of CCI-779, a novel mammalian target of rapamycin kinase inhibitor, in patients with advanced refractory renal cell carcinoma. J Clin Oncol. 2004; 22: 909-18.

35. Smith JW, Ko Y-J, Dutcher J, et al.: Update of a phase 1 study of intravenous CCI-779 given in combination with interferon-a to patients with advanced renal cell carcinoma. J Clin Oncol. 2004; 22 (Suppl. 14): Abstract 4513.

36. Amato RJ, Misellati A, Khan M, Chiang S: A phase II trial of RAD001 in patients (Pts) with metastatic renal cell carcinoma (MRCC). J Clin Oncol. 2006 ASCO Annual Meeting Proceedings. 2006: 24; No. 18S (Suppl 20). Abstract 4530. Available at: http://www. asco.org/portal/site/ASCO/menuitem.34d60f5624ba0 7fd506fe310ee37a01d/vgnextoid=76f8201 eb61a7010 VgnVCM100000ed730ad1RCRD\&vmview=abst_detail_view\&confID $=40 \&$ abstractID $=34073$
37. Motzer RJ, Escudier B, Oudard S, Hutson TE, Porta C, Bracarda S, et al.: Efficacy of everolimus in advanced renal cell carcinoma: a double-blind, randomised, placebo-controlled phase III trial. Lancet. 2008; 372: 449-56.

38. George D, Michaelson D, Oh WK, Reitsma D, Laurent D, Mietlowski W, et al.: Phase I study of PTK787/ZK $222584(\mathrm{PTK} / \mathrm{ZK})$ in metastatic renal cell carcinoma. Proc Am Soc Clin Oncol. 2003; 22: (abstr 1548). Available at: http://www.asco.org/portal/site/ASCO/ menuitem.34d60f5624ba07fd506fe310ee37a01d/ vgnextoid=76f8201 eb61a7010 VgnVCM100000ed7 30ad1RCRD\&vmview=abst detail view\&confID $=$ 23\&index $=y$ \&abstractID $=10 \overline{2} 273$

39. Rini B, Rixe O, Bukowski R, Michaelson MD, Wilding G, Hudes G, at al.: AG-013736, a multi-target tyrosine kinase receptor inhibitor, demonstrates anti-tumor activity in a Phase 2 study of cytokine-refractory, metastatic renal cell cancer (RCC). J Clin Oncol. 2005; 23: (Suppl 16S, Part I of II) Abstract 4509. Available at: http://www.asco.org/ASCO/Abstracts+\&+Virtual +Meeting/Abstracts?\&vmview=abst_detail_view\&c onfID $=34 \&$ abstractID $=30051$

40. Hutson TE, Davis ID, Machiels JP, de Souza PL, Hong BF, Rottey S, et al.: Pazopanib (GW786034) is active in metastatic renal cell carcinoma (RCC): Interim results of a phase II randomized discontinuation trial (RDT). J Clin Oncol 2007; 25: (Suppl. 18S Part I). Abstract 5031. Available at http://www.asco.org/ASCO/Abstrac ts $+\&+$ Virtual+Meeting/Abstracts?\&vmview=abst_detail_view\&confID $=47$ \&abstractID $=33945$

41. Ravaud A, Gardner J, Hawkins R, Von der Maase H, Zantl N, Harper P, et al.: Efficacy of lapatinib in patients with high tumor EGFR expression: Results of a phase III trial in advanced renal cell carcinoma (RCC). J Clin Oncol. 2006; 24 (Suppl. 18S Part I). Abstract 4502. Available at:http://www.asco.org/ASCO/Abstr acts $+\&+$ Virtual + Meeting/Abstracts? \&vmview=abst detail_view\&confID $=40 \&$ abstractID $=33904$

42. Figlin RA, Kondagunta GV, Yazji S: Phase II study of volociximab (M200), an a5fl1 anti-integrin antibody in refractory metastatic clear cell renal cell cancer (RCC). J Clin Oncol 2006; 24: (suppl). Abstract 4535.

43. Kondagunta GV, Drucker B, Schwartz L, Bacik J, Marion S, Russo P, et al.: Phase II trial of bortezomib for patients with advanced renal cell carcinoma. J Clin Oncol. 2004; 22: 3720-5.

44. Dupont J, Rothenberg ML, Spriggs DR, Cedarbaum JM, Furfine ES, Cohen DP, et al.: Safety and pharmacokinetics of intravenous VEGF Trap in a phase I clinical trial of patients with advanced solid tumors. $\mathrm{J}$ 
Clin Oncol. 2005;23: (Suppl. 16S, Part I of II). Abstract 3029.

45. Bleumer I, Knuth A, Oosterwijk E, Hofmann R, Varga Z, Lamers C, et al.: A phase II trial of chimeric monoclonal antibody G250 for advanced renal cell carcinoma patients. Br J Cancer. 2004; 90: 985-90.

46. Ross R, Srinivasan R, Vaishampayan U, Bukowski R, Rosenberg J, Eisenberg P, et al.: A Phase 2 Study of the Dual MET/VEGFR2 Inhibitor XL880 in Patients (pts) With Papillary Renal Carcinoma (PRC). International Conference on Molecular Targets and Cancer Therapeutics. 2007; (Abstract B249). Available at: http://www.exelixis.com/eortc/posters/AACR_NCI EORTC2007_XL880_phase2.pdf
47. Fyfe G, Fisher RI, Rosenberg SA, Sznol M, Parkinson DR, Louie AC: Results of treatment of 255 patients with metastatic renal cell carcinoma who received high-dose recombinant interleukin-2 therapy. J Clin Oncol. 1995; 13: 688-96.

48. Vogelzang NJ, Lipton A, Figlin RA: Subcutaneous interleukin-2 plus interferon alfa-2a in metastatic renal cancer: an outpatient multicenter trial. J Clin Oncol. 1993; 11: 1809-16.

49. Dawson NA, Guo C, Zak R, Dorsey B, Smoot J, Wong J, et al.: A phase II trial of gefitinib (Iressa, ZD1839) in stage IV and recurrent renal cell carcinoma. Clin Cancer Res. 2004; 10: 7812-9.

Accepted after revision: December 5, 2008

\section{Correspondence address:}

Dr. Flavio Lobo Heldwein

Altamiro Guimaraes, 360 / 504

Florianopolis, SC, 88015-510, Brazil

Fax: + 5548 3223-0816

E-mail: flavio.lobo@gmail.com 